\title{
The diverse understandings of foreign migration to the South of Brazil (1818-1950)
}

Giralda Seyferth

Professor of Anthropology, Museu Nacional, Universidade Federal do Rio de Janeiro

\section{Abstract}

In this text I analyze some of the conceptual and subjective meanings of the notion of immigration, observing how these are appropriated in the debates on foreign colonization that influenced immigration policy in Brazil during the nineteenth century and the first half of the twentieth century. I also discuss everyday representations of immigration contained in writings by German immigrants sent to colonize areas of southern Brazil, exploring the liminal identity that emerges as a result of the difficulty experienced settling in still untamed areas of Brazil. The text examines understandings of immigration more directly associated with the colonization process promoted by the Brazilian state, still included in the 1945 Law of Foreigners, through which large areas of uncultivated lands in the south of the country were occupied by European immigrants (and their descendants) in the form of family smallholdings. Under these circumstances, German immigration preceded other flows of migrants, despite Brazilian nationalistic concerns over assimilation.

Keywords: immigration; foreign colonization; nationalism; identity.

\section{Resumo}

Neste trabalho pretendo discutir alguns significados mais gerais da fundamentação conceitual da imigração e as apropriações e substituições do termo que estão presentes nos debates sobre as políticas de colonização estrangeira no Brasil, objeto de polêmicas desde o século XIX. Em contrapartida, a análise contempla as representações de senso comum de 
imigrantes alemães acerca da imigração e da conseqüente identidade liminar produzida pela decisão de se estabelecer, em caráter definitivo, no Brasil. O trabalho aborda os entendimentos da imigração associados mais diretamente ao processo de colonização privilegiado pelo Estado brasileiro, inclusive na legislação correspondente, no longo percurso histórico que vai de 1818 até meados do século XX.

Palavras-chave: Imigração; colonização estrangeira; nacionalismo; Identidade. 


\section{The diverse understandings of foreign migration to the South of Brazil (1818-1950)}

Giralda Seyferth

Professor of Anthropology, Museu Nacional, Universidade Federal do Rio de Janeiro

\section{Introduction}

The word immigration usually indicates a particular dimension of international migration that presupposes the settling of people and groups in a foreign country - the synthesis found in etymological dictionaries and encyclopaedias. This is a basic and apparently fixed definition, enunciated in theory and certainly present in nationalist discourses and the symbolism associated with the new identities that emerge in receiving countries. In this text I discuss some of the more general meanings of the conceptual basis of immigration and the appropriations and substitutions of the term that are present in the debates on foreign colonization policies in Brazil, a polemical subject since the nineteenth century. By contrast the analysis explores the everyday representations of German immigrants concerning immigration and the consequent liminal identity produced by the decision to settle definitively in Brazil. The article explores the understandings of immigration more directly associated with the process of colonization favoured by the Brazilian state, including the corresponding legislation, which occurred primarily in the three southern states during the lengthy historical period spanning from 1818 to the mid-twentieth century.

During this period there was greater government interest in sending European immigrants to new 'colonial nucleuses' based around family smallholdings, an idea expressed in the regulations on foreign entry into the country. Under the Brazilian Empire and Republic, the immigration laws successively promulgated until the mid-twentieth century were also colonization laws, with the official designation colono (colonist, settler) very often 
appearing as a synonym for immigrant. Following the end of slavery in 1888 , the state of São Paulo became the biggest receiver of immigrants because of the need for a labour force on the large farm estates, in the expanding industrial sector and in urban services. On the other hand, even in the south, many foreigners preferred to settle in the cities. But this legal format persisted under the Law on Foreigners which came into force in 1945 at the end of the Second World War, despite that these new immigrants had little interest in moving to new rural colonies. After the First World War colonization was mainly undertaken by the descendants of immigrants. These factors explain the periodization adopted in this text.

The empirical grounding to the present text includes two sets of documents and publications examined over a long-term perspective. The analysis of the assertions on immigration/colonization contained in the discourses denoting formal concern with settlement of the national territory is based on the relevant legislation and on official publications (produced by individuals linked to the state apparatus) of an immigrationist or nationalist bent.

Another set of documents and publications provides empirical support to my observations on the understanding of immigration and the formulation of a related new identity by the immigrants themselves. In this case the texts are diverse in kind, narrating the individual experience of transnational movement: letters, memoirs, articles published in local newspapers, biographies, historical accounts and so on, held in public and private archives. Many of these documents were published on the initiative of descendants or scholars of colonization, or through the 'Original Documents' section of the journal Blumenau em Cadernos, published by the Blumenau Cultural Foundation. I have discussed the methodological importance of these sources in another text (Seyferth 2005: 13-51). Despite their subjective nature, these documents are useful so long as we look at them within the context in which they were produced (in this case, foreign colonization in the south in Brazil), remembering that they were written by individuals who talk about themselves but also about social processes without any concern with chronology: the time of the accounts is, above all, the time of memory. 
In the preface to the collection of texts by A. Sayad on Algerian immigration in France, Pierre Bourdieu defines the immigrant as someone out of place:

Like Socrates, as described by Plato, the immigrant is atopos, has no place, and is displaced and unclassifiable. The comparison is not simply intended to ennoble the immigrant by virtue of the reference. Neither citizen nor foreigner, not truly on the side of the Same nor really on the side of the Other, he exists within that 'bastard' place, of which Plato also speaks, on the frontier between being and social non-being. Displaced, in the sense of being incongruous and inopportune, he is a source of embarrassment. [...] Always in the wrong place, and now as out of place in his society of origin as he is in the host society, the immigrant obliges us to rethink completely the question of the legitimate foundations of citizenship and of relations between citizen and state, nation or nationality. (Bourdieu2004: xiv).

The comments underscore Sayad's analytic perceptiveness, of course, but also have the virtue of highlighting the immigrant's imprecise condition, a perturbing element of national identity. The discomfort caused by the liminality surrounding the immigrant's condition is related to the development of nationalism over a period of approximately one century prior to the First World War, a time also marked by the mass immigration of Europeans provoked by the expansion of colonial empires and the formation of new States, especially in the Americas. As Hannah Arendt (1976) astutely observed, the nation state imagined by nationalism does not easily coexist with the more embarrassing 'others', given the former's primordialist ideal of community that transforms the State into an instrument of the nation, which meant the subordination of citizenship to the principle of nationality. Among the 'others' (or 'non-nationals') were the undesired immigrants, the stateless, refugees, minorities and other categories organized in political and social fields after 1918, that is, in the post-war context marked by innumerable reconfigurations of international borders and the attempts to consolidate the League of Nations.

The subject 'embarrassing everywhere' identified by Bourdieu shapes the very definition of immigration since the immigrant's social and political condition practically 'deterritorializes' him or her, bearing in mind the general principle of national identity forged under modernity. 
I have no intention here of entering into the interminable debate on the concept of the nation, ${ }^{1}$ suffice to recall that the modern meaning of the term gave a new dimension to the idea of the State, particularly in the nineteenth century (which for many scholars of nationalism only came to an end in 1914). The problem posed by the ideal of the nation state conceived by nationalism resides in the difficulty in defining what a nation is, or, as Hobsbawm (1990: 5) observed:

[...] the chief characteristic of this way of classifying groups of human beings is that, in spite of the claims of those who belong to it that it is in some ways primary and fundamental for the social existence, or even the individual identification, of its members, no satisfactory criterion can be discovered for deciding which of the many human collectivities should be labelled in this way.

The question of the criteria used to recognize national identity is clearly apparent in the political movements of collectivities as part of their demand for autonomy as nation states, while often remaining indefinitely in the condition of national minorities, sometimes in a situation of inequality. At the same time, human mobility over the course of modern history also disrupted the formation of the nation state idealized by nationalism, grounded in the (supposed) cultural, ethnic and linguistic unity of the 'national community,' without ignoring the political dimension. According to Gellner (1983), nationalism as a feeling or movement can be best defined via a political principle: it contains a theory of political legitimization. Yet for various reasons nationalism is intolerant of cultural diversity and adverse to legitimizing a pluralist political system. Nationalism engenders the nation through cultural artifices, arbitrary histories and invented traditions, but cannot be considered merely an ideology.

Weber (n.d., 1991) situated the concept of the nation in the sphere of values, emphasizing the importance of 'national feeling' and 'national solidarity,' the belief in the existence of a 'national communion' steeped in references to the community of language and culture. In an unfinished text written at the end of the First World War, Mauss (1969) also calls attention to the principle of nationality (forged in Romanticism) that symbolically expresses

1 The different ways of conceiving the nation as a political and cultural reality can be observed in the collections edited by Hutchinson \& Smith (1994) and Balakrishnan (2000). 
the nation's existence. In everyday representations the nation merges with nationality, possessing a negative content - the revolt (or hatred) directed towards the foreigner and expressed in the disease of national consciousness. For Mauss, all the Europeans wars since the Napoleonic era, including the First World War, were nationality wars.

These considerations indicate a series of conceptual problems, identified with a certain irritation by Max Weber (1991), given the symbolism of nationalism and the principle of nationality, which attribute greater importance to the cultural, linguistic and primordial dictates (or naturalized belonging) of the nation's formation than to political reason and citizenship.

The beginning of European emigration to Brazil coincided with the formulation of a kind of ethnic theory of nationality inherent to Romanticism and expressed in its purest form by Herder, who considered the nation a cultural whole associated with a people (Volk), and by Fichte, creator of the notion of Volksgeist (spirit of the people). The two philosophers were key figures in the initial phase of Romanticism and took as their empirical reference point the 'German nation' based on linguistic and cultural unity without any correspondence to a politically and territorially unified State (finally made concrete in 1871). Ethnic, cultural and linguistic manifestations, reinforced by the notion of folklore (and its links to 'popular culture'), persisted in the formulation of national identities and strengthened the feelings of belonging and xenophobia. Hobsbawm (1990: 131) writes that ethnic nationalism was exacerbated in the second half of the nineteenth century by the increase in geographic migration and racism (which precipitated the convergence of race and nation), as well as linguistic nativism (whose symbolic meaning prevailed over actual use of the language). Indeed the ideal of the nation state proclaimed by nationalism supposes a sovereign territorial and political entity and a univocal national community composed of a people, a culture and a language. The cultural, linguistic and other differences produced by immigration - even when the latter is considered necessary and encouraged - are generally perceived to be a danger: a threat to the unity of the State. This 'naturalized' conception of the nation extols particularism, opposing the foreigner (and strangers in general) to the national. In this liminal situation, the immigrant is a foreigner, or, to invoke the term's etymology, an individual who is not native to the country where he or she is found, pertaining to another nation and requiring naturalization (including to be considered a citizen), 
a situation that does not necessarily guarantee equal recognition. The idea of naturalidade, nativeness, includes the place of birth. However the term also contains an ambiguity insofar as it suggests that nationality involves sharing an identity linked to an historical and cultural heritage and, sometimes, to a primordialist language of common kinship (or origin). 'Naturalization' assures citizenship rights to the immigrant through a form of 'adoption,' which does not necessarily include the attribution of a new national identity.

Understandings of the phenomenon of migration have varied over time, including in Brazil. Simplifying from the word's etymology, migration indicates the relocation of individuals and groups across geographic space. Modern human migration, for its part, concerns the intercontinental movements of people since the sixteenth century, associated with colonialism and, as part of the context of the formation of new states in the nineteenth century, with the emigration of Europeans (and others), initially with some degree of freedom but later increasingly controlled by more restrictive government policies.

As Ferenczi observes (1933), the intercontinental migrations of Europeans during the nineteenth century helped solve problems of unemployment and demographic growth in their home countries. Precisely for this reason, public regulation of emigration and immigration was more relaxed, reflecting the strength of the spontaneous waves of migration. Hence while the colonizing countries exported paupers and convicts to their overseas colonies (and here the reference is almost always to the occupation of Australia), the countries that did not possess colonies would, at moments of economic and political crisis, subsidize emigration, especially of the poor, vagrants, the unemployed, revolutionaries and other problematic social categories - a practice with various repercussions in the countries receiving these immigrants. The abolition of slavery also stimulated emigration, particularly in the period from 1830 to 1870 . These observations are important for two reasons: first, they indicate the two complementary processes making up theories of international migration - detailed in encyclopaedia entries ${ }^{2}$-that refer to leaving a country of birth and entering a receiving country, and second, they emphasize the European historical juncture that favoured emigration, a matter of interest to the Brazilian government since 1824 .

2 Migration theories were more intensely debated after the First World War and their importance can be observed in the diverse (and lengthy) articles contained in the Encyclopaedia of the Social Sciences, published in 1933 by Macmillan. 
The theoretical constructs surrounding migration show the difficulty in formulating a single theory to explain a heterogeneous set of social, economic, demographic and political phenomena that, in diverse ways, interest the different disciplines in the fields of Geography and the Human and Social Sciences. Hence the variety of conceptual expressions used, very often in the form of dyads (internal/international migration, temporary/permanent, colonization/labour migration, legal/illegal), or the adjectives employed to qualify migration, sometimes referring to different historical periods, such as primitive, modern, free, voluntary, forced, mass and so on (see Cohen 1996).

My interest here involves keeping the more general meaning of 'modern migration,' a concept related to multiple forms of mobility, including movements from rural to urban areas (linked to industrial development). However it also includes migrations across international borders, controlled in some form by government policies from the nineteenth century onwards when the nation state became consolidated just as the European diaspora increased to other continents. These policies covered emigration and immigration, both subject to public regulation and, as Ferenczi observed (1933), more relaxed control in the nineteenth century for two reasons: greater freedom to emigrate due to the support and sometimes subsidies granted by some governments for the departure of its unemployed and poor citizens; and the opening up to (European) emigration by some new States, in particular the United States, Argentina and Brazil. Slowly this relative freedom at the two poles of international migration drifted into more restrictive policies which changed how (im)migration was understood, introducing new categories of undesirables. In many ways, migration can be understood as a movement that was voluntary but controlled within the ambit of the nation state, since domestic policy prevailed, even after the creation of international organizations (the League of Nations, the United Nations) in the twentieth century.

According to its initial formulation in the theoretical field, immigration presupposed the entry of people into a foreign country with the intention of forming part of the life of this country and making it their more or less permanent place of residence. Such is the definition given by Ware (1933) in describing European mobility and its economic and cultural implications. This interpretation could be said to align with the nationalist discourse in those countries receiving European immigrants, perceived as a potential element in the formation of the people (and thus the nation), despite the asymmetry that 
accompanies this kind of premise, frequently connected to the idea of assimilation. It can also be perceived in the everyday discourse of European immigrants in the modern era, particularly in the period prior to the First World War, divested of the assimilationist ideal sometimes present in the receiving country, indicating the immigrants' liminal social condition and the rupture needed to construct their new identity. Both perceptions can be observed in the discourses and practices concerning European colonization in Brazil.

\section{II}

The official understanding of immigration and its potential role in national development varied considerably in Brazil, even taking into account the government's interest in attracting European settlers, a constant aim during the first half of the twentieth century, including within the New State's Immigration and Colonization Council (1937-1945). European colonization began before independence, soon after the promulgation of Ordinance 08/02/1817, which regulated the entry and expulsion of foreigners. In this case 'foreigner' was someone in a temporary situation, not definitively established as worker or trader, and the decree encouraged the expulsion of those without a passport or legitimation card.

In 1818 negotiations involving the Portuguese and Swiss governments cleared the way for the installation of a colony on the Morro Queimado Farmstead in the Cantagalo district of Rio de Janeiro state, later named Nova Friburgo. The official documentation regulating the localization of the Swiss immigrants contains the general principles that guided the colonization system after independence, based on poly-culture (to produce food supplies) on smallholdings employing a family workforce. It is not my intention to analyze the causes of this international migration (basically related to the agrarian crises that affected various European countries at the start of the nineteenth century) since my main focus is on how the migratory process has been perceived.

The word immigration was not part of the official lexicon, although it was presupposed in the principal categories used: colono and civilização. In Decree 06/05/1818, D. João VI ruled that the civilization of the Kingdom of Brazil should be promoted by augmenting the population with people skilled in various types of work (agricultural and industrial), bringing in Swiss settlers during this first phase. Here settler is synonymous with immigrant, 
while civilization evokes Europe. Settlers could be naturalized once established, acquiring the status of vassals of the king (in accordance with Decree $16 / 05 / 1818)$. The arrival of foreigners on a definitive basis, which constitutes the common sense definition of immigration, appears clearly in the legal texts, though these also speak of family-based colonization as part of a civilizing process. At the same time, the only reference to the biological characteristics of the immigrants appeared during the raising of a Swiss militia of 150 men aged between 18 and 40 to form battalions of whites alongside the Portuguese contingent.

The reference to skin colour also appears later in the context of a debate on the settling of German migrants in Rio Grande do Sul, in an official document issued on 31/03/1824 which asserted the "superior advantage of employing white and industrious people, both in the arts and in agriculture" (see Rocha 1918, v.1: 182). Colonization was resumed with the foundation of São Leopoldo in July 1824, this time in the southern region, considered demographically 'empty' and under threat from Argentina. In the legislation anticipating the immigration processes, including Law 30/10/1823 which instituted Brazil's provincial governments, colonization was qualified as 'foreign' yet the terms immigration and immigrant were absent. The foreigners sent to these starter colonies were identified as colonos, settlers, followed by their nationality of origin. The presupposition of staying in the country permanently, for its part, appears clearly in the various naturalization laws promulgated from 1832 onwards that sought to regulate the residential status of the settlers, albeit with some restrictions since naturalization was not available to those who had lost their civil rights in their country of origin. It also involved a lengthy bureaucratic process.

The flow of settlers (in this case German) was interrupted in 1830 and, save for some private initiatives authorized by the province of Santa Catarina that proved unsuccessful, the imperial government only resumed foreign (European) colonization in the mid-1840s during a wide-ranging debate on the new land law and abolition of the African slave trade. ${ }^{3}$

In 1848 those provinces interested in promoting colonization (both domestic and foreign) received control of some of the unoccupied lands. The

3 The law abolishing the slave trade was promulgated the same year as the Land Law, 1850,a fact equally related to the project of occupying empty lands with immigrants. The existence of the slave trade was considered by the advocates of foreign colonization one of the obstacles to attracting European settlers. 
same proposal appears in the Land Law (Law 601, issued 18/09/1850), which among other things defined unoccupied lands and ruled that they could only be granted through sale to private companies and for the establishment of colonies. The law created space for colonization through private companies or associations formed for this purpose and approved by decree by the State Office of Imperial Affairs. Although colonies with Brazilian settlers did exist, colonization remained closely tied to immigration. In this case use of the term colono, settler, rather than immigrant is highly significant. The arguments made by the Empire's Ministers in favour of foreign colonization, both before and after the Land Law, included the use of propaganda to encourage emigration to Brazil, yet in the actual legislation the figure of the settler stands out. The expression "import European settlers" was also frequently used during the imperial period, principally when European emigration appeared in progressive discourse as the best way to 'replace' slave labour, recalling here that trading in slaves was sometimes referred to as 'importation.'

The colonization planned by the imperial government focused on the three southern provinces and Espírito Santo, specifically in areas where there were no expanding slave-based plantations. At the same time, though, the possibility of the eventual abolition of the slave trade stimulated the introduction of a partnership system with European settlers in the São Paulo coffee plantations in 1847 - a polemical topic in Europe since it suggested a model of substituting slaves with immigrants that hinted of servitude. In both cases immigration was designed to meet the interests of the Brazilian state in populating unoccupied lands, and in satisfying the demand for labour on the coffee estates (especially in São Paulo). The immigrant was subsumed under the common denominator of colono, settler, but with different meaning. In São Paulo the term colono indicated an immigrant working to contract (almost always on abusive terms) in coffee cultivation. ${ }^{4}$

The legislation regulating the entry of foreigners during much of the Empire seldom contained the word immigration (or immigrant). The term emerges more frequently from the mid-186os in the legislative acts approving the statutes of companies wishing to recruit and dispatch settlers to the São

4 In the case of São Paulo, immigrants were subordinated to the interests of coffee growing. The unfavourable contractual conditions resulted in various settler revolts. According to Beiguelman (1978), the accumulation of funds by immigrants would often led them search for better opportunities in farming (as smallholders) or in the cities. 
Paulo estates or to new colonization areas, or in the contracts signed between the imperial government and private agencies.

In summary, during the Empire settler and immigrant are classificatory terms used to designate either a generic European or, sometimes, a specific European nationality and an accompanying hierarchy of preferences in terms of which nationalities were chosen. While in some cases the reference is to 'European settlers,' in other cases apparently random nationalities (or regionalities) are specified, significantly associated with the work factor. Two examples shed light on this pattern: in Decree n. 5.663, issued on 17/06/1874, Joaquim Caetano Pinto Junior is contracted to import 100,000 German, Austrian, Swiss, northern Italian, Basque, Swedish, Danish and French immigrants, "healthy, hardworking and moralized farmers" (with up to $20 \%$ of them belonging to other professions); in Decree n. 5.699, issued 31/07/1874, Colonel José A. A. Pereira is contracted to introduce 4,00o immigrant in the province of Paraná, the nationalities varying slightly since now Germans, Belgians and Basques are joined by Lombards, Swedes and Slavs. Here we encounter a conception of directed immigration, congruent with the system of foreign colonization, while the $20 \%$ of immigrants from other professions was designed to meet the demand for skilled tradesmen in the cities.

The legislation does not detail the nationalities that were given priority. This appears to have been given to those with a vocation for agriculture and the arts/trades. The hierarchy of nationalities is clearly set out in a variety of publications from people linked to the State apparatus, such as the Marquis of Abrantes and the Counsel Menezes e Souza (from the Ministry of Agriculture, Trade and Public Works): in these publications, the Germans invariably appear in first place. , a fact not reflecting alphabetic order. As Menezes e Souza specifies (1875: 403), the Germans had a taste and talent for immigration, persevered, loved work, and passed easily from the trade of craftsman to the profession of farmer - in sum, they were the 'settlers par excellence.'

This kind of evaluation of the settler immigrant was extended to other European nationalities since the initial German flow was numerically supplanted by immigrants from other areas of Europe, notably Italians. The ideal of Brazilian nationhood was shaped within the parameters of western civilization. The civilizing rhetoric, only suggested in some legal texts, appears emphatically in the majority of the writings by advocates of immigration, which contain categorical assertions such as, for example, a phrase 
introducing Tavares Bastos's reflections on immigration in a text published in 1867 , commissioned by the International Immigration Society:

Emigration ceased to be, like the exodus of the Hebrews, forced exile and became the most effective instrument for civilization on the planet. (Tavares Bastos 1976: 51)

At more or less the same time, the afore mentioned Counsel Menezes e Souza claimed that a 'fertilizing exodus' should leave the Teutonic countries (and other less favoured regions of continental Europe) for Brazil, a fairly unusual way of alluding to European emigration. Here I do not intend to discuss the idea of racial inequality present in this type of argument, which extols the civilizing quality of the European immigrant, emphasized more strongly at the end of the nineteenth century. However we can observe that immigration was linked in racial discourse to the idea of the formation of the people, a key element of assimilationist nationalism. This connection produced another premise that would mark in particular the more radical variants of race-based republican nationalism during the first half of the twentieth century. These in turn influenced the ways of defining which immigrants were desired, despite the almost monolithic acceptance of the civilizing qualities of European immigration. Here I refer to the dual aspect of the assimilation process advocated in the ideal of forming the nation. On one hand, there was the belief that the Brazilian population could be whitened through selective miscegenation with white immigrants. On the other hand, these same immigrants should desist from maintaining any cultural plurality, becoming properly integrated into the Luso-Brazilian organization of the nation. ${ }^{5}$

Assimilation cannot be considered a relevant theme in the discussions of foreign colonization policies during the Empire period, given the greater interest in populating the Brazil's territory as part of its progress. For this reason colonization was criticized by nationalist sectors from the mid-nineteenth century onwards, concerned above all with the multiplication of 'German colonies' in the south. The numerical preponderance of Germans in colonization areas until the start of the 1870 s was used to define a certain type of undesirable immigrant, white and civilized but with the tendency to form 'enclaves' due to

5 On the importance of this nationalist racial ideal in the discussions on immigration policy, see Seyferth (1991 and 2002). 
their distance from Latin cultures. Germans - and later, under the Republic, the Japanese - headed the lists of the 'unassimilable' in the two senses cited above. The idea of an unequivocal 'Latinness' stands out in the assimilationist arguments made in favour of Italian, Portuguese and Spanish immigration all nationalities imagined to have the potential to integrate, including racially, due to their linguistic, cultural and religious proximities. Seen in terms of integration, the continuance of German immigration was considered a risk for the principle of nationality and for the security of the territory -hence the fear of an 'invasion' of Protestant Germans which became prominent from the $1870 \mathrm{~s}$ onwards in a discourse brimming with xenophobia from some of the more radical nationalists, and codified at the end of the nineteenth century in the expression 'the German peril' in response to Pan-Germanist propaganda.

The data presented, although limited, show different ways of understanding immigration and specifying the particularity of specific immigrants. The 'enclaved', 'unassimilable' were undesirable and contracted with the 'Latin' who were considered more compatible with the formation of the Brazilian nation. The nationalist view was not opposed to foreign colonization: yet, the ideal settler is easily assimilated, placed in contact with Brazilian nationals in mixed colonies.

The principle of nationality also had repercussions for naturalization. On this point, we can note the use of the term foreigner instead immigrant since the first law regulating the attribution of nativeness in 1832. In legal terms, the naturalization card was issued under the Empire to foreign applicants who met certain requirements (aged over 21, possessing civil rights in their country of origin, time of residence in Brazil, declaration of religious and patriotic principles, and so on). In practice naturalization involved a complicated bureaucratic process and many of the foreigners able to apply were settlers located in pioneer areas. Hence one of first measures of the provisional government of the Republic in relation to immigration was to consider as Brazilian citizens all those foreigners residing in Brazil on 15/11/1889, save for a declaration to the contrary in the municipality concerned.

The Republican government sought to regulate the situation of numerous immigrants who had been living in the country for decades without citizenship at a moment of considerable increase in the flows of immigration. But the question of assimilation persisted. It was felt that naturalization gave foreigners civil rights but did not transform them into actual Brazilians. This 
led to an interminable debate on 'nationalization' or 'Brazilianization'. The significant increase in European immigration at the turn of the twentieth century, particularly of the desired 'Latins,' helped exacerbate the belief in whitening the population, another element considered essential to ensuring that Brazil could became included in western civilization, though as a nation state singularized by its Luso-Brazilianness. In spite of the (slow) discrediting of the theories that preached racial inequality and opposed (indiscriminate) miscegenation in the name of white superiority, these ideas concerning the formation of the Brazilian nation persisted until the mid-twentieth century. Even though divested of direct references to race, they were essential in planning the forced assimilation of immigrants and their descendants through the 'nationalization campaign' pursued by the New State (1937-1945).

The misplaced critique of the methods of foreign colonization in the Empire marked the discussion of immigration in the First Republic, but failed to have much practical repercussion. Legally immigration remained linked to colonization, falling under the responsibility of the Ministry of Agriculture, Trade and Public Works (and its General Inspectorate of Lands and Colonization), reflecting the primary interest of the federal government and some state governments in the entry of settlers (whether farmers or artisans). There was no specific restriction on immigrants trained in other professions, whether arriving with their families or not, who preferred to settle in urban areas. They needed to comply with the general qualifications demanded of ideal immigrants (including settlers) also in force during the Empire: healthy, educated and morally upstanding individuals with an aptitude for work, under the age of 60 , and with no criminal past. However Decree 528, issued 29/06/1890, which regulated the introduction of immigrants, imposed virtually insurmountable difficulties to the entry of "natives from Asia or Africa". This was later revoked for immigrants from Japan and China in 1902 due to the federal government's desire to establish diplomatic and commercial relations with those two countries, and the interest of São Paulo's coffee growers in hiring Japanese settlers, reputed to be 'good agriculturists'. The racial question implied here generated fierce debates because of the nationalists' rejection of the arrival of more people they imagined to be unassimilable (see Seyferth 2002). The essential fact, however, resides in the agricultural qualification of the preferred immigrant. The only assimilationist stipulation - non-existent in the Empire's legislation - can be found in 
Article 42 of the cited Decree: $25 \%$ of the total number of immigrant families admitted in the colonial nucleuses should be nationals, "hardworking, educated and apt for the agricultural service". The idea of a 'mixed colony' (including Brazilians citizens and immigrants of different nationalities) is implicit in this stipulation which, during the expansion of colonization, also met the demand for lands of the descendants of European immigrants.

The model of localizing immigrants in colonial nucleuses remained the same under the Republic, families being established on 'lines' with plots of approximately 25 hectares. On the other hand, it should be observed that during the Empire the entry of European settlers was requested (and even stimulated) without significant restrictions, except those related to age and criminality. ${ }^{6}$ On this point, the most evident change in the conception of immigration and the immigrant after 1889 can be seen in the restructuring of the ministry responsible and in the decrees creating and regulating the Settlement Service. Through Decree 1.066, issued on 19/12/1906, the federal government created the Ministry of Agricultural, Industrial and Commercial Affairs (MAIC) responsible for immigration and colonization and for catechizing and civilizing the indigenous population. Shortly after Decree 6.455, issued on 19/04/1907 laid out the framework for the National Land Settlement Service. ${ }^{7}$ In its second article, it defines the immigrant as follows:

Those accepted as immigrants shall be foreigners under the age of 60 , without contagious disease, not exercising an illicit profession, nor recognized as criminals, troublemakers, beggars, vagrants, lunatics or invalids, arriving in national territory with third class tickets...

The same wording reappears in Decree 9.081, issued on 03/11/1911, which established a new framework for the Settlement Service, covering immigration and colonization with the addition that second and third class passengers could now be admitted as immigrants. ${ }^{8}$ Here immigrants are primarily

6 Criminality was a common topic in the discussions on immigration policy due to the absence of control over the practices of agencies hired by the government, very often accused of "emptying the European prisons."

7 .The MAIC was only regulated in 1909:until then the Settlement Service was part of the Ministry of Industry, Roads and Public Works. In fact there was just a change in the name, emphasizing agriculture!

8 The continuation and privileging of colonization with immigrantsis clearly evident in this decree. It comprises 26 chapters and 277 articles regulating in detail the localization of foreign settlers in the colonial nucleuses, as well as the introduction of immigrants. 
qualified by their 'moral conditions'. However, we can note the clear association with poverty contained in the allusion to third class passengers. At the same time the legislation on immigration remained embedded within the legal regulation of colonization, now openly announced as settlement. To a certain extent the ideal immigrants for the federal government were those sent (by the State or by authorized companies) to a colonial nucleus and who were obviously moralizados and 'apt' for work, thereby replicating the Empire's aims in relation to immigration. In that decree, the imperial model of colonization, criticized by republican nationalism, is very clearly evident in article 140, where the 'colonial line' is defined as "a carriage way bordered by measured and demarcated lots, adjacent or close to each other, allocated for settlement by immigrants as land owners."

Immigration and colonization therefore continued to be coupled with legislation that focussed on populating the country, with families with an aptitude for work. It also instituted general guidelines for introducing and settling immigrants with precise rules on entrance into the country. The law was promulgated during the 'great immigration,' a historical period when the numbers of foreigners entering Brazil were at their highest, before falling significantly after 1914. Paradoxically, despite the continuation of the policy of establishing colonial nucleuses, most immigrants were sent to the state of São Paulo because of the demand there for labour on the coffee plantations and in the expanding industry, or sought to work on the urban job market, especially in the south, including in the towns and cities emerging in the old colonization areas. The large volume of entrants was probably one of the reasons for imposing more rigorous controls, especially given the eugenicist pronouncements in discussions of the 'immigration problem,' also debated by social thinkers analyzing the formation of the Brazilian nation (see Seyferth 2002). In this case, the representation of dangerous immigration includes the negative image of immigrants who were sick (the fear of contagious diseases), elderly (not 'apt' for work) or lacking morality: racial issues were dissimulated in the wider legislation, but formed part of the intense political and academic debate around 'whitening,' which presupposed the exclusion of non-white people, which appeared in its more radically racial form in the works of João B. de Lacerda and Oliveira Vianna, for example. ${ }^{9}$

9 See Lacerda (1911), Oliveira Vianna (1938). The first edition of Oliveira Vianna's book, significantly 
Other evidence of closer control of entry lies in the establishment of immigrant hostels from 1890 onwards These were run by the Union or the States, and were designed to receive those foreigners who had been identified as immigrants. This identification suggests an understanding of immigration as the settlement of immigrants in the country. It was based on a distinction made in some legal texts between simple foreigners and the immigrant foreigners who were subject to more stringent restrictions. In the 1930s, these obstacles increased with the inclusion of political-ideological and ethnic criteria for evaluating immigrants. On this point, Decree 24.215 , issued on 09/04/1934, is emblematic since as well as the cases specified previously, it also prohibited the entry of drug addicts, the illiterate, people with physical and/or mental disabilities, people with a history of conduct harmful to public order or national security, and Roma people.

The premise of living permanently in the country, which makes the immigrant a potential participant in the nation's formation, foregrounds the process of naturalization, especially the early legal form granted in 1889 . The requirements, applicable to new immigrants only, were established in 1902: to obtain naturalization, the applicant had to present an identity document (passport), be over the legal age of majority, have resided in Brazil for a minimum of two years and prove to have a clean police record (attested by official documents). Later changes to the rules were relatively insignificant, such as an eventual increase in the required time of residence in the country. Under the New State, the omnipresent issue of national security prevailed, allowing naturalization to be refused to those immigrants deemed "harmful to the country's order, security and prosperity."

In the 1930 and especially under the New State, what were once laws regulating immigration and colonization became laws on foreigners. They maintained the regulations on the settlement of colonial nucleuses. There was a drastic reduction in European immigration, while Japanese immigration increased along with the demands from stateless people and refugees. The obstacles to foreigners then increased in general. A quota system for 
immigrants was introduced in 1934 and maintained in Law Decree 406 of 04/05/1938, and in Law Decree 7.967 of 18/09/1945. The formulae used to calculate these quotas ${ }^{10}$ favoured the immigrants desired by republican nationalism (Portuguese, Italian and Spanish), an important indicator of the weight given to the ideal of assimilation, the political base of forced nationalization elaborated by the Immigration and Colonization Council in collusion with sections of the military.

The first direct mention of assimilation in a legal text appears in the aforementioned Law Decree 406. Assimilation and its corollary, the 'melting pot' (or the crisol de raças, 'crucible of races,' in the Brazilian expression), formed part of the discussion of immigration policies and appeared as a regular theme in the pages of the Revista de Imigração e Colonização, an official publication that served as an outlet for texts by members of the Immigration and Colonization Council. On this point, Article 2 of the decree leaves no doubts about the kind of immigrats that were sought:

The Federal Government reserves the right to limit or suspend, for economic or social motives, the entry of individuals of particular races or origins, after hearing from the Immigration and Colonization Council.

The proviso obviously appears after the usual list of undesirables. Assimilation is also in the title to Chapter VIII, which stipulates the formation of colonies with immigrants from at least three distinct nationalities, and more than $30 \%$ of Brazilians. The Council had the right to prohibit the settling of foreigners who compromised "the ethnic or social composition of the Brazilian people." The ideal of assimilation reappeared in Decree 3.010, of 20/08/1938, which ruled on the period of residence requires, the distribution and assimilation of foreigners with the aim of preserving the 'ethnic constitution' of Brazil. Here we can observe the continuation of immigration within the campaign for the nationalization of aliens, a classification that presumes the absence of a sense of Brazilianness, including among descendants and naturalized citizens who maintained some degree of cultural distinctiveness.

Immigration is seen, therefore, as a process of complete incorporation into the new nationality, whose traditional bedrock is the 'Iberian substratum'

10 The foreigners admitted as immigrants each year could not exceed $2 \%$ of the number of individuals of the same nationality who had entered in the period from 1884 to 1934 . The largest flows of migrants during this period came from Italy, Portugal and Spain. 
(of language, culture and character). Ribeiro Couto (1941), who believed in the effectiveness of assimilation, argued for its inclusion in the Law of Foreigners. His use of the terms ethnic and ethnic group fails to conceal the racial nature of his understanding of assimilation (based on the notion of the melting pot) and reveals the belief in the whitening of the population. As Couto put it:

However great our goodwill, however deep our instinct for international cordiality, it falls to us to defend the morphological characteristics of the Brazilian people, preserve its possibilities of getting closer to the founding European types, keeping apart the Asiatic groups and preventing their development. Hence the Japanese problem is from the start an immigration policy problem. (Couto 1941: 22).

The comments reveal the kind of thinking prevailing in the New State's Immigration and Colonization Council concerning the formation of the Brazilian people. It is particularly significant that he made no reference to Africans since they were not even imagined as immigrants. Asians, however, especially the Japanese, were treated as high-risk immigrants, who should be subject to police control. Another defender of the 'ethnic' control of immigration, Artur Hehl Neiva, a prominent member of the Council, provides a good idea of the scale of the question, discussed in the 1934 Constitutional Assembly, where there were no lack of proposals for ensuring the entry of 'white people' only, excluding immigrants from the "black and yellow races," made by influential politicians like Miguel Couto, Xavier de Oliveira, Artur Neiva and so on.These claimed that "the problem has beset the conscience of the nation" (Neiva 1944: 516). Neiva suggested an immigration policy linked to the "categorical imperatives of national security" which would involve the selection of immigrants "from eugenic, ethnic and political aspects." From this viewpoint, the policy was consistent with the ideal of whitening, demanding the favouring of "white immigration and reducing or, preferably, excluding black and yellow immigration" (Neiva 1944: 578). Concluding his text, Neiva lends support to the 'wise' policy of placing restrictions on the stateless, a detail that calls attention to other problematic categories in the context of international migrations, present in the lexicon of exclusion since the 1920s, among them refugees and national minorities.

The two texts cited above, along with others of the same ilk published in the same journal by authors like Oliveira Vianna, A. Lima Câmara, Gavião 
Gonzaga, Lourival Câmara among others ,, influenced the drafting of the new Law of Foreigners promulgated at the end of the New State (the aforementioned Decree 7.9670 1945) and which remained in force after the war. The law remained wedded to the dictates of national security, while the second article authorized the exclusion of immigrants that threaten to dilute the characteristics of European descent in the population's ethnic makeup. The connection between this desired immigration and progress is contemplated in the law, which shows continuity in the mid-twentieth century of the developmentalist and civilizing goals advocated in the Empire period.

This radically assimilationist nationalism reached its apogee during the Vargas era, and was manifest in xenophobic demonstrations. In this climate, the very definition of immigration as a definitive process of settling foreigners in the country demanded the renunciation of their previous nationality (through naturalization) and of their cultural past. The forced nationalization that interfered with symbolic and practical violence in the everyday life of groups of immigrants and their descendants from 1937 onwards (see Seyferth 1999: 285-330) was a precise indication that immigration and naturalization were imagined differently by the immigrants themselves.

\section{III}

The perception of the meaning of immigration for immigrants themselvescan be observed in testimonies written by settlers from different social strata in their country of origin. ${ }^{11}$ In these writings, immigration is almost always presented in the etymological sense of the word, emphasizing the fixing of residence in the receiving country, but at the same time describing the immigrant as someone out of place, in search of a new identity, and confronting the ambiguities of naturalization.

The Editorial of the launch issue of the newspaper Kolonie Zeitung, founded in 1862 on the initiative of Ottokar Dörffel in the D. Francisca colony (Joinville, Santa Catarina state), is a good example of the liminality inherent to this transition. It is particularly relevant here since it expresses the

11 The term colono was employed, including officially, to designate any individual established in a colonization area, including residents of the settlements dedicated to trade and craft, some having emigrated for political motives, others with university training involved in educational and cultural activities, and so on. 
opinion of an important local leader, with a revolutionary past, inaugurating the German-language press in Santa Catarina. ${ }^{12}$ Dörffel emigrated to the colony in question after being attracted by the propaganda of the 1849/Hamburg Colonization Society, a company promoting colonization in lands owned by the Prince of Joinville, received as a dowry on the occasion of his marriage to D. Francisca, sister of Emperor Pedro II.

Dörffel's biography is not that of a common settler, as becomes clear in the obituary published by the Kolonie Zeitung on 20/11/1906. ${ }^{13}$ Born in Waldenburg, Saxony, in 1818, the son of a public servant, he trained in Law in 1842, in Leipzig. He worked as a lawyer and, in 1847 , became a court clerk in Glauchau: two years later he became the town's Burgermeister (mayor). In this capacity he became involved in the revolutionary events of 1848 , participating in the conflicts that occurred in the Kingdom of Saxony in 1849. After the failure of the revolution, he faced a criminal inquest for high treason: he was condemned and later pardoned by the king. He always denied requesting the pardon (the starting point for the process) and faced various trials in the Dresden Superior Court, receiving absolution in 1852 . His connection with the 1848 revolution prevented him from returning to a normal life in Glauchau, leading to his decision to emigrate. ${ }^{14} \mathrm{As}$ a result, he considered himself an exile, a status alluded to in the Editorial of the Kolonie Zeitung cited above. His importance in the cultural and political life of Joinville (the name given to the D. Francisca colony after

12 The Kolonie Zeitung - the first German-Brazilian newspaper in Santa Catarina - circulated almost without interruption until 1942. It was published in Portuguese between 1938 and 1942, meeting the New State's nationalist demands for 'Brazilianization.'

13 The biographic data are taken from Dörffel's obituary, translated by Elly Herkenhoff and included in a publication with a small print run, intended for the divulgation of historical documents - Arquivo Histórico de Joinville, Year 1, Number 1, October 1983.

14 A large number of participants from the movement emigrated, especially to the United States. The 1848 revolution in Germany mobilized different social groups, including the bourgeoisie and the liberal middle class, workers, peasants, communists (with the participation of Karl Marx and other 'revolutionary philosophies') in search of political and social reforms, taking as a background the ideal of unification of the diverse German states into a federation. Many armed conflicts took place, including in Berlin (see Carr 1979). Dörffel took part in one of these episodes, occurring in Dresden, leading two contingents of revolutionaries who left Glauchau. It is interesting to note that he settled as an immigrant on lands belonging to the Prince of Joinville who, out of financial necessity following the outcome of the 1848 revolution in France (which resulted in the fall of the King Louis Philippe), decided to found a colonization company. Dörffel's emigration to Brazil prompted some of his compatriots to do the same given his status as a local political leader: this was the case of Cristian Strobel, who wrote an account of his 'pioneering' trajectory, published in 1987, cited by Machado (1998) who studied the emigration of the Strobel family to Paraná. 
the settlement was given municipal status in the 1870s) is signalled in the local historiography. Indeed he distinguished himself as a journalist, co-founder and supporter of cultural and recreational associations, and author of books on local history and guides for emigrants wishing to settle in Brazil's south. He was elected a local councillor and, as president of the Municipal Chamber, held the post of mayor between 1873 and 1876 .

The content of the Editorial reflects the trajectory of an opinion maker and community leader, and provides a clear picture of the immigrant as someone between two homelands. The first paragraph of the Editorial explains this liminal situation with some precision:

Fatherland (Vaterland)! What a sublime fascination this name holds, and on pronouncing it, how we stand tall, how our chest swells - but how many feelings, for us painful, are connected to it! The true fatherland (Vaterland), with its gentle recollections of our youth, and everything that became dear to us through education and everyday habit-we have left behind: distant, infinitely distant, it is found behind us, and probably we shall probably be separated from it forever! And the new land in which we have built our home and to which all our existence is connected? This new land has still not become a homeland (heimish) for us. It still does not seem to want to accept us as its children and the deeper the affection with which we try to connect with it, the more we feel strangely repelled, not infrequently- and the more impetuously reignite the yearning for the old and unforgettable homeland (Heimatland) - the homeland that, in truth, has already lost sight of us and forgotten us. Really, what an embarrassing and disheartening situation we live in, when made stateless (Heimatlosen [literally 'homeless']) - we do not know to whom we belong, so to speak!"'15

The use of the term apátrida, stateless/homeless, is significant since it highlights the immigrant's condition as someone lacking any real identity, an individual without national belonging, located in a spatial and temporal vacuum. The notion of pátria, homeland, is not unequivocal, however, since the author refers to belonging to a nation state,${ }^{16}$ and to the more affective

15 First paragraph of the first page of the launch issue of the Kolonie Zeitung newspaper, translated by Elly Herkenhoff, divulged in the cited publication in note 13. The German language has two terms equivalent to the Portuguese pátria, homeland and fatherland, show in parentheses in the transcription.

16 At the time (1862) the process of unifying the German states was yet to be concluded, but Germany 
and cultural meaning associated with land and home. The double meaning appears in the alternating use of the words Vaterland and Heimatland: the first opens the text and has an ample signification (including political), referring to Germany, while the second establishes the belonging associated with a mother tongue and culture, which would later be ethnicized, including through German-language newspapers, eventually producing a GermanBrazilian identity. Thus Heimatland, or simply Heimat, represents a form of territorialization in the ethnic sense, one which can occur outside the country of birth. Dörffel's discourse indicates that this has yet to happen, since immigration produced a rupture with the 'true Vaterland', leaving the immigrant without a homeland (heimish). Moreover the text expresses the difficulty of Brazilian society in accepting foreigners, indicating his awareness of the assimilationist - and at times xenophobic -discourse of nationalist sectors that had long seen German immigration as a threat to nationality, at least since the 1860 s, due to the cultural, linguistic and religious differences between Latins and the Germans. This was an argument of little concern to the champions of foreign colonization, who indeed maintained a critical stance in relation to the more exaggerated rhetorical claims that immigration represented a form of invasion. ${ }^{17}$

It is important to note that, despite his use of the term stateless, immigration is conceived in Dörffel's account as a journey without return. This idea is implicit in his reference to his new home, that can combine both homelands, depending simply on the immigrants' perseverance. In this way hope replaces discouragement:

With a firm will and perseverance we can renew our relations with the old homeland [...] making them increasingly vivid and thus expanding[...]the old homeland until it reaches us -not in space, undoubtedly, but spiritually. Acting continuously and persistently, in accordance with our German character and spirit (echtdeutschen Sinne und Geiste), we can also gain the respect and affection of the new homeland, making our relationship with it happier. Thus we will have double of what we just had in single measure beforehand.

(Deutschland) was already a political reality for the nationalist movement.

17 A defence of immigration, in a response to nationalist xenophobia, can be observed in the work of Carvalho (1875). 
The argument contains a principle of German-Brazilianness, later widely proclaimed in the German-language press, which advocated belonging to the new homeland without losing the connections (mainly cultural and linguistic) with the Urheimat (or'old homeland'). Indeed establishing a definitive home in the receiving country, assuming the identity of an immigrant of German character and spirit, signals a kind of thought contrary to the ideal of assimilation, which gradually moved from nationalist discourse to Brazilian legislation on foreigners as the twentieth century unfolded. The newspaper launched by Dörffel in the Dona Francisca colony in 1862 defended German-Brazilianness and the cultural plurality arising from immigration in general over the next 80 years, as well as the sentimental, affective and also economic connection to Germany, the homeland 'of origin.'

The perception of the immigration process as a rupture that is later resolved by ethnicity appears with other comments in memoirs and letters sent by immigrants to their family members. The written recollections of Pastor W. G. Lange, leader of a group of German migrants who had left so-called 'Russian Poland' (referring to the Polish territory under the control of the Czarist Empire) in 1886 to form a colonial nucleus in the area run by the 1849 / Hamburg Colonization Society, adhere to the same framework of ethnic nationalism. The feeling of rupture emerges in a section describing the voyage:

On the afternoon of the $18^{\text {th }}$ the brothers, with their luggage, climbed on board [...] followed by myself on the $19^{\text {th }}$. At 3 o'clock the steam began to bellow out. Ah, how hard it is to turn one's back on one's homeland!

$[\ldots]$

For how long? Or forever? Reader, you know the answer. Yes, it was forever. $[\cdots]$

The port of São Francisco was as beautiful as the city was poor. But of the latter we saw little, since early in the morning a small steamboat came from Joinville to pick us up [...] The 'Hamburg' sets off and the last column of smoke slowly disappears over the horizon. The last connection with the old homeland is broken. Were someone to have told me that it would be forever! But now it was essential not to look back, but to push on instead. After 2 hours travel we arrived on the afternoon of June 29th in the pleasant town of Joinville and finally we set foot on our new homeland.

(Lange 2003: $76,78,85$ ). 
The image of the boat sailing away from the port and intensifying the liminality of the immigrant appears in other texts, almost with the same exact phrasing. It appears, for example, in the account of the experience of Clara Hermann, recently married, ${ }^{18}$ who emigrated to Santa Catarina in 1903 :

The crossing lasted four weeks and my sea sickness the same. [...] We were still aboard at Christmas and that was the last time I saw a German Christmas tree, the one we had brought with us. Amid the tumult of the preparations for the journey I had given no thought to saying goodbye to the motherland, since it was still Germany on the boat. But when we were in the port in São Francisco, watching the ship sail into the distance, I suddenly felt with a heavy heart that I had left everything behind and that I was now in an unknown country.

$[\ldots]$

In São Francisco I felt as though I were in a foreign country, but Joinville dissolved this impression, here you only hear German spoken and the town has the look of a little German village.19

In both cases the author emphasizes the feeling of bidding farewell to the homeland, symbolized by the ship returning to the ocean. The 'unknown' is the village of São Francisco do Sul, the port of arrival, a place of transition. The symbolic rupture with Germany, expressed as the will of God by Pastor Lange, or in her last view of a 'German Christmas tree' by Clara Hermann, gives a definitive meaning to immigration just as much as the immigrant's resigned bewilderment as he or she enters a foreign country, an impression that soon faded before the cultural landscape produced by colonization. In this sense, Joinville is a familiar place with the distinctive marks introduced by German immigration (preponderant in the region) since 1851, including everyday use of the maternal language. According to their written memoirs, Lange and Hermann stayed overnight in São Francisco do Sul before setting off for Joinville, but for both the new homeland was there, in the colonial

18 Her marriage took place in Germany to a German immigrant who had already settled in the Itajaí Valley. He had returned to his 'original homeland' to visit his sister and find a wife.

19 Clara Hermann's manuscript belongs to the José F. da Silva Historical Archive, Blumenau Cultural Foundation. It was published (in a bilingual edition) in the magazine Blumenau em Cadernos under the title "Vivências de Clara Hermann," translated into Portuguese by Annemarie F. Schünke. See Blumenau em Cadernos, XLII (11-12): 15-17. 
region populated largely by people of German extraction. The final destination of the group led by Lange was a new colonial nucleus called Brüderthal, while Clara Hermann headed to the colonial lot belonging to her husband, in the HansaHumbolt colony. ${ }^{20}$ Joinville, though, with its familiar Germanic air was an example of what Waibel (1958: 206) called 'self-contained communities' related to the socioeconomic and cultural characteristics of European colonization. After all, according to the cultural and spiritual configuration of the Heimat found in Romantic nationalism, the homeland could be territorialized in any country, obviously maintaining the language, habits, customs and other conventional elements of belonging, which also include other principles highlighted by Weber (1991) in his discussion of 'ethnic communities' (including those resulting from migration).

The discomfort generated by the vague nature of the immigrant, as someone wavering between two homelands, is a transitory feeling, therefore, given the perception of the definitiveness of the immigrant's trajectory and the possibility of making a home in a Germanicized region where the two main urban nucleuses - Joinville and Blumenau - evoked 'small German towns' (something indeed emphasized in the propaganda used to attract immigrants, and in the more flattering literature on colonization). In principle this image contains a paradox since it defines the immigrant in relation to two incompatible nationalist reference points, although the keyword is pátria, homeland. But even the feeling of statelessness expressed by Dörffel evaporates with the possibility of reconciling the belonging to two homelands (one of them 'spiritual') by maintaining the idea of Germanness (Deutschtum) on Brazilian soil. The double belonging and cultural singularity contained in the idea of Germanness was widely backed in the German-Brazilian press including in the Kolonie Zeitung founded by Dörffel until its extinction in 1939.. For Brazilian nationalism, immigrants only ceased to be awkward and disturbing foreigners when lawfully naturalized and assimilated.

Back in Germany, however, the emigrated citizen might no longer be included among the national population, an eventuality that becomes clear in a short remark made by Clara Hermann. Recounting the meeting

20 The two names have since changed: Bruderthal (Vale of the Brothers) - a religious community reference - is the present-day municipality of Guaramirim, while Hansa Humbolt gave rise to the municipality of Corupá. The change in the names occurred for nationalist reasons, a common event in areas of foreign colonization in the twentieth century. 
with her future husband, a German who had emigrated to Brazil but had returned temporarily to look for a wife in Germany, Hermann reveals that he was classified as a Brasilianer (Brazilian). This designation was probably unrelated to the formality of becoming naturalized in Brazil: rather it reveals the situation of the migrant who is no longer recognized as a national by his society of origin. ${ }^{21}$ Consequently Dörffel's aim of reconciliation contrasts with the social and political reality faced by the immigrant in search of a German wife. Brazilians 'drüben' (on the other side), ${ }^{22}$ Germans here! Indeed in the representation of the 'others' we encounter an individual suspended between two homelands, asserting his or her dual nationality. This duality or duplicity, widely discussed in the German-language press and fictional literature, ${ }^{23}$ presumed a German-like everyday life in a homeland (Heimat) situated on Brazilian soil. In this sense, the immigrant is völkisch, a word widely used to distinguish the feeling of an ethnicized national belonging. Weber (1991: 269-271) signalled the importance of customs, habitus and linguistic community in shaping ethnic groups, including those produced by emigration. Immigrants can adapt well to a new environment, but also tend to maintain feelings of ethnic communion related to the country of birth in a context of a life shared in common. Weber alluded to the 'conscience of community' inherent in such situations.

The Germanic peculiarity of the colonial region of Santa Catarina state where the immigrants cited here lived is also stressed in writings by travellers, or even by migrants who returned. As an example, we can take the text entitled "Some days in Germany", included in a travel book by Willi Ule. The author visited various regions of Brazil and passed through the Itajaí Valley, which he refers to as 'Germany':

21 At the time becoming naturalized in another country meant losing one's nationality. A few years later, Germany promulgated the Delbrück Law, allowing immigrants and their descendants to retain their German nationality. However, the attribution of a Brazilian identity to the immigrant was an aspect of their social relational context, rather than a reflection of his or her legal position. The Delbrück Law caused a polemic in Brazil, where it was linked to Pan-Germanism and seen as a boost to the pretensions of a German-Brazilian dual identity.

22 A term used (even today) to refer to Germany, at the same time reinforcing the position of immigrant (or descendant).

23 The fictional literature (tales, novels and poetry) in the German language emphasized GermanBrazilianness and community life in the colonization areas until 1939, when it was prohibited during the nationalization campaign. See Huber (1993) and Seyferth (2004). 
For some time I really lived only with some Germans, practically heard only German, saw only German faces and ate food made in the German style. The destination was the German colony of Blumenau, in the State of Santa Catarina.

$[\ldots]$

And in Germany we complained that our compatriots from overseas had rapidly lost their Germanness. Here they maintained their culture for decades under adverse conditions and with much strife.24

The visitor's account undoubtedly reflected the fine welcome he had received in Blumenau, and diverges little from the widespread everyday local perception, which had a negative impact in the nationalist sectors of Brazilian society worried about assimilation. From the nationalist viewpoint, Blumenau was a paradigm of 'ethnic enclaves' incompatible with the principle of Brazilianness.

The same 'Germany' in Brazil appears in the writings of Therese Stutzer, author of tales, short stories and letters that contain details of everyday life in the colonial region of Blumenau, where she lived with her husband, the Evangelical pastor Gustav Stutzer, in the 188os. For her the region could be recognized by the Germanic cultural characteristics maintained by the settlers in an exuberant Brazilian landscape. The very title of Therese's bestknown work is a good example of this combination: Deutsches Leben am Rande des brasilianischen Urwaldes: German life on the edge of the Brazilian jungle. It represents the perception of a frontier civilization described by a migrant returned to the homeland. In one of her letters she complains of the 'empire of untamed nature' and the sensation of being close to Germany provoked by the arrival and departure of ships in the port of Itajaí, through which the correspondence sent to her relatives and friends was sent. ${ }^{25}$

The 'untamed nature' depicted in the writings of Thereze Stutzer matches the Romantic vision of an untouched and exuberant natural landscape, transformed into an obstacle to the advance of colonization in the view of another woman who returned to Germany, and who wrote about the plight

\footnotetext{
24 From the text published in the magazine Blumenau em Cadernos, 49(1): 9, 17. According to editorial information, Willi Ule was a specialist in Marine Sciences linked to the Berlin Geographic Society.

25 See Letter of Therese Stutzer, 08/07/1886, published inBlumenau em Cadernos, XXXIX (8), 1998, pp. 9-11. Also see Stutzer (1886). The publications on the Brazilian experience of Therese and Gustav Stutzer were very popular in Germany and many new editions were published until the 1920s.See Fouquet (1974).
} 
represented by her experience of immigration in the south of Brazil between 1907 and 1911. In the work of Emilie Heinrichs, entitled "The wife of the emigrant: the experience of a settler's wife in the south of Brazil, ${ }^{26}$ a question of gender comes to the fore and drives the narrative: the subaltern position of women.The objective of the author's account of her experience in a colony with 'pioneer zone' characteristics, located in a forest region of Rio Grande do Sul, was to alert her female compatriots to the dangers and difficulties encountered in her problematic experience of emigration. The text was published in Germany in 1921, ten years after the Heinrichs couple had returned and in the middle of the economic and political crisis of the Weimar Republic, a period marked by significant numbers of emigrants, including to Brazil. ${ }^{27}$

The key fact prompting the publication of her experience as an emigrant was her husband's decision to leave the homeland without taking into account her opinion. She was simply expected to accompany him. She emigrated against her will because "the woman has no decision." Boarding the ship in Hamburg, ready to set sail for Brazil, with a strong feeling of homelessness (Heimatlos), she wrote of leaving Germany and heading off for the unknown:

I do not want to speak of all the pain and suffering of the farewell: I felt homesick for my country even before leaving it. All the women who have experienced the harsh fate of emigration may share this feeling. We become just like a child looking for the first time on a distant world, already feeling homeless (Heimatlos). (In: Blumenau em Cadernos, 51(6):19).

Describing the ship's departure, she notes the same feeling of rupture present in other accounts:

We arrived in time to see the last rope fall to the ground, the one still connecting the ship to the land. The old and loved German flag rose on the main mast. [...]The last tie with my land was broken. (In: Blumenau em Cadernos, 51(6):23).

The text shows the author's frustration with emigration, reflected in her use of the term Auswanderer (emigrant) as a criterion for identification, and in the constant reference to the desired return, which she admits to being her

26 Full text published in a bilingual edition in six issues of the magazine Blumenau em Cadernos, in the 'Original documents' sevction. See Blumenau em Cadernos, 51(6), 2010 and 52(1-5), 2011.

27 In the 1920 B Brazil received more than 6o,ooo German emigrants. Many returned before the Second World War, but even so the number of entrants was the highest for a single decade since the beginning of German immigration. 
only thought, finally achieved almost five years later. At no moment did she imagine her situation to be irreversible. She does not describe herself as an immigrant (Einwanderer), making it clear at the end of her account that she never found a 'new homeland' because this destiny requires more than finding work and food in a foreign country.

Her residence in a colonial nucleus recently founded in the interior of Rio Grande do Sul, which lacked the same degree of Germanic singularity evinced, for example, in the writings of Ottokar Dörffel and Clara Hermann, was probably the determining factor in her decision to return, more so than the difficulty of the settler's life. On this point Emilie Heinrichs's account coincides with that of João Weiss, an Austrian who emigrated to the same colony region with his family in 1912 at the age of 15 . Both stress the lack of information as to the true situation of colonies located in the middle of the forest, denouncing the illusory propaganda used by agencies that promised lands in abundance and other benefits, but omitted the 'untamed forest', the painful work of clearing the land, and the fact that settlers would be left to their own devices in an unknown environment. The confrontation with the forest, a recurrent theme in this type of literature, involves the description of a sombre, almost impenetrable space with gigantic trees and dangerous animals, which must be put into a condition to be cultivated through the labour of the settler and his family alone. The forest, finally vanquished, gives way to crop cultivation and self-sufficiency in food, but the arduous task of clearing and planting fails to lead to the desired social improvement. Or, in terms of Weiss (1949: 10), the emigrant "devotes himself to his exhausting work, drowning the intense bouts of homesickness" (for the homeland and civilization) but remains facing an indefinite future in the new country. Weiss did not return 'to the homeland,' but left the colony in search of a better life in the city. Return and internal migration did not represent failure, therefore, since the taming of the forest was made possible by 'arduous work': nonetheless, the emigrant needs to know exactly what he or she will find, a place far from civilization.

Another point in common in the two accounts is the immigrants connection to poverty, employing the same principle of classification found in the Brazilian legislation during the same period: a third class passenger, travelling on the lower decks of the ships. Emilie Heinrichs makes the connection when describing the embarkation of three thousand Polish and Russian to 
the United States, identified by the word Zwischendecker (a reference to the passages on the middle deck, located right above the cargo hold). João Weiss makes more direct use of the expression 'third class' to describe the family's voyage from the port of Trieste, precisely in this situation. The Heinrichs travelled in a cabin shared with other immigrants, possibly second class, showing that poverty was not the reason for emigration, perhaps a form of ignoring the common sense premise concerning the definitiveness of immigration present in Weiss's discourse. ${ }^{28}$ Describing the transatlantic journey, he depicts the third class berths in a dramatic manner:

We numbered about five hundred emigrants [...] third class passengers, huddled in collective dormitories, separated into men and women, poorly ventilated and dark (Weiss 1949: 13).

The connection between immigration and poverty is usually made clear. In an anonymous text by an immigrant who arrived in the colony of Blumenau in 1856 , we find a useful summary that reinforces the poverty argument. After mentioning the precarious dwellings of the Stadtplatz $z^{29}$ and the shelter of 'deplorable appearance' allocated to newly-arrived settlers, people who had already experienced many difficulties during the Atlantic crossing, the unidentified author remarks:

Really I know numerous travel and immigration companions who even today have tears in their eyes when they recall the homeland and the friends left behind. And so many years have already gone by! The land where one was born and grew up stirs deep feelings. I'm sure nobody manages to forget completely. But most people have no wish to return, even if they could, since here they find what it is impossible for the poor back in Germany to obtain: freedom and property.30

The colony's founder, Hermann Blumenau, thought likewise since his colonization project, which was initially planned for mass immigration that

28 Heinrichs does not state the profession of her husband, apparently seduced by seduced by the prospect of having 'his own tract' and become a farmer in the new country. Her intention was to dissuade potential emigrants, expressing the joy of setting foot once more on the 'homeland soil.' João Weiss's father owned a shoe shop and, it seems, was equally captivated by the idea of land.

29 A term commonly used in the colonization period to designate the 'urban centre' of a 'German colony.' Blumenau, in 1856, was merely a small village on the shore of the Itajaí-Açu River.

Extracted from the original document published in Blumenau em Cadernos, XLVIII (3-4), 2007: 13-14. 
failed to occur, had sought to help compatriots with no future in Germany, believing in the viability of a new homeland in Brazil while maintaining the German language, customs and culture. The proposal to colonize a large area of unoccupied land in the south, mentioned in the letters sent to the Brazilian Consul in Prussia, J. J. Sturz, between1844 and 1852, ${ }^{31}$ was rejected by the imperial government, which only approved the project for the middle Itajaí-açu Valley, where the colony was founded in 1850 . In the letters he takes on the immigrants' 'cause,' associating emigration with the limitations placed on the social mobility of the subaltern classes and on demographics, an issue widely debated, including in academic circles, in Germany before unification,.

The anonymous immigrant, describing the precarious infrastructure of the colony established in the middle of the 'dense jungle', asserted that everything could be overcome through the work of 'brave settlers,' the majority 'extremely poor' ${ }^{32}$ who would never become landowners in Germany. The reference to freedom, on the other hand, also reflects the historical period of mass German emigration: the crisis among the peasantry caused by the advance of capitalism into rural areas, the growth of the lumpen proletariat, and the defeat of the revolutionary movements of 1848 by Prussian militarism.

There are no indications of a political kind in the anonymous text, but the Itajai Valley saw the establishment of immigrants coming from the German peasantry who had left the country following the outcome of the 1848 revolution. In colonial nucleuses where collective demonstrations were held to demand better conditions, the leaders of the settlers were associated with the revolution and identified by the administrators as 'communists' (see Seyferth 1999). This type of locally confined social movement, even during the Empire, contradicted the idea of the morally upstanding immigrant, dedicated to work, and, settled on his/her colonial lot. Socialists, communists and criminals in general had been considered a risk to the State's security since the mid-nineteenth century.

However there were socialists among the immigrants, such as Josef Umann, another 'settler in the jungle', and author of a memoir whose central theme is the poverty that induced the search for a new homeland, which to

\footnotetext{
31 Hermann Blumenau's letters are reproduced in the work edited by Vogt (2004).

32 The original word is Blutarm, anaemic, and was probably used in a double sense: poverty and physical exhaustion. The text contains many references to diseases and rotten food, common complaints during the so-called 'pioneer phase.'
} 
a certain extent responds to the question "Who should emigrate?" Umann"33 tells his life story from his childhood in Bohemia to the arduous settlement in Linha Cecília, a colonial region located in the municipality of Venâncio Aires (Rio Grande do Sul). As described in his account, the immigration process excludes any prospect of return and the immigrant is left to build his own world, in this case, the community called Linha Cecília.

Umann writes that he came from a poor family and needed to labour hard from childhood in a situation of "rationed food and abundant work" (Umann 1981: 9). He became an orphan at the age of thirteen and, separated from his siblings, was sent to Vienna as a tinker's apprentice. On returning to Bohemia he learnt glass polishing, an insalubrious 14 hours a day job. In this harsh context, socialist activism was the only positive element, allowing him to dream of improving the fate of the working class. However his despair over the living conditions of workers, with no prospect of better days to come, eventually persuaded him to emigrate. He left the homeland with his wife and daughter to try his luck as a settler in the Brazilian south, along with another 150 Bohemians, most of them workers from the glass factories.

The Umann family emigrated in 1877 , a period when the expression 'third class' was yet to form part of the definition of the immigrant. In fact the crossing of the Atlantic was considered good, leaving aside the seasickness. The subaltern position of the immigrants became clear, though, on the coastal steamer taking the group from Rio de Janeiro to the port of Rio Grande: the Bohemians were moved from their berths to make way for wealthier passengers who paid more, leaving them 'packaged' in a small area with barely space to sit.

Umann's exposition of the colonization process talks of the difficulties of clearing the land as other writers: the exhausting land journey to the colonial nucleus, the felling of the "dark virgin forest with its colossal trees", the construction of the "first tiny and improvised shack", the food rationed before the first harvest and other "miserable circumstances" during Linha Cecília's beginnings.

Though not adopting the critical stance of Emilie Heinrichs concerning the lack of information provided on the true conditions of the settlement deep

33 Umann's (incomplete) memoirs, with additions made by his children, was published in a bilingual edition, translated, introduced and annotated by Hilda A. Hübner Flores. She observes that the text was actually published in German during the Second World War but almost all the copies were confiscated. See Umann 1981. 
in the forest, Umann (1981: 61-62) explains that "few immigrants know exactly what the term jungle means" and even these "will find the initial period in the forest much more difficult than they had imagined." Hence the forest is a formidable obstacle for "a man in a foreign land who wishes to build a home for himself and his family." A poem he wrote, called "Who should emigrate?" (Wer soll wandern?) elaborates on the immigrants' problems. The individual who migrates is without hope and without future, unable to provide a home for his family, a situation that justifies travelling to the unknown where there might be a tract of land for him and where, despite the initial difficulties, "he can console himself with the hope that everything will be better in the future." The last part of the poem expresses the definitiveness of immigration and the transmutation of the socialist factory worker into an immigrant settler:

And when he has his own house,

And his land farmed,

He finds himself happy amid

A world built by himself.

(Umann 1981: 82).

Umann's memoirs refer to the beginnings of colonization, but the biographical information added by his children contain records of his cultural activities and his important role as a community leader and co-founder of associations that celebrated German ethnic belonging, such as the Song, Reading and Shooting Societies. The 'constructed world' is depicted, therefore, as a place of tranquil community life after the arduous phase of colonization, a new homeland (Heimat) in Brazil adapted to the principles of Germanness contested by Brazilian nationalism.

The lack of perspectives prompted the search for better existential conditions in another country as immigrants, far from the homeland, and the difficult crossing in inadequate berths (which at the end of the nineteenth century became part of the discourses of immigrants in the expression 'third class' as a synonym of poverty), are topics that form part of the set of representations relating to immigration, the immigrant and the 'pioneer' life, observable in the letters and memoirs of settlers of other nationalities. Italian and Polish immigrants also played an important role in the expansion of the colonization process after 1875 , and their mode of understanding immigration is practically identical to the Germans (who preceded them), presuming 
the definitive nature of their move to Brazil and a new community life enabled by hard work, later ethnicized through cultural distinctions.

The letters of Polish immigrants, published in a volume edited by Kula (1977), and the letters and occasional memoir written by Italians, Germans and Poles, transcribed by Stoltz (1997), provide good examples of this perception of immigration. The settlers who write of their experiences, generally to family members, emphasize the feeling of rupture with the homeland, sometimes mentioning boarding the ship in the country of origin, or landing in Brazil, the initial difficulties involved in clearing the forest, the precarious dwelling conditions in the lots, the high mortality rates, the diseases, the lack of doctors, the poor diet and other problems of the 'pioneer' life (cited even today as one of the diacritics of ethnicity). However they also declare their belief in future progress, a better life than back in their homeland, something that presumes immigration as a definitive process. This belief is particularly evident in the letters written by Polish immigrants, most of them from the 189os (see Kula 1977). These were sent to the wives and other relatives close to the letter writers, telling them how they left the homeland, at the time still under the political control of the Czarist Empire. ${ }^{34}$ Despite the problems faced during the voyage and, later, in the colonial areas where they were sent by the Brazilian government, particularly in Rio Grande do Sul where epidemic outbreaks of small pox and other diseases occurred, with a high mortality rate among the newly arrivals, the letters encouraged others to emigrate to Brazil, speaking of the freedom found there, religious support and the possibility of becoming landowners. Some letters reveal the intention of bringing women and children, without the knowledge of the Russian government, after they had become properly settled on a 'colonial line' (written, therefore, by family fathers who had travelled alone). But the more frequent argument is simple: even the most adverse circumstances could be surmounted and life in Brazil was better than in the homeland. These are letters with a strong religious tone and in them we can also perceive the importance of Catholicism in shaping the identity of the Polish immigrants.

34 Most of the Poles who entered Brazil between 1890 and 1914 came from so-called 'Russian Poland' and figured in Brazilian statistics as 'Russians.' Emigration was motivated by economic reasons and equally by the absence of political freedom aggravated by the assimilationist process of 'Russification' (which also affected the Germanic national minorities from the same area, the motive behind the emigration of the group led by Pastor Lange, cited previously). 
The prosperity of the settlers who arrived in earlier periods and the coexistence with compatriots, sometimes coming from the same region, or acquaintances met during the voyage across, are emphasized in these personal documents, indicating the formation of a community with shared cultural attributes. Linha Cecília, where many of the Bohemians emigrated at the same time as Josef Umann had settled, is a good example of this kind of community organization. In practice the 'communities' formed in the colonial nucleuses received national adjectives (as 'German,' 'Italian' or 'Polish' colonies), expressing not only the numerical prevalence, but also cultural and ethnic distinctions.

\section{IV}

Foreign colonization in Brazil, begun prior to independence - resumed in 1824 and further extended after 1850 , principally in the three southern provinces - was designed as a policy for occupying public lands as part of a civilizing process. The Imperial State wanted settlers, a category implying small family producers directly linked to taming uncultivated lands. They should be civilized (and thus European), and able to work in agriculture, arts and trades. The terms immigration and immigrant only appear occasionally, even in legislation where the predominant references are to colonization and colonos (settlers) sometimes qualified by a particular European nationality. Restrictive measures underlay the definition of the ideal settler, who should be morally upstanding, healthy, a qualified worker without a criminal history. Problems relating to the integration and assimilation of the immigrants were pushed into the background during the implementation of the immigration policy consistent with the sense of progress implied by the double meaning of the term inculto - uncultivated lands and the absence of culture or civilization. Hence immigration was defined as a directed and definitive process of settling European colonos, without restricting the entry of immigrants with another occupational profile.

However the nationalist principle of Luso-Brazilianness formed the basis for a critique of the model of foreign colonization favoured by the State since the mid-twentieth century, introducing an intense debate on the difficulties of assimilating foreigners who remained isolated in the colonial nucleuses. As far as nationalism was concerned, immigration could only be perceived as 
a definitive process of integrating foreigners into Brazilian society and culture, when they renounced their linguistic, religious and cultural singularity. German immigrants were the main targets of a nationalism that argued in favour of 'Latin' immigration and repudiated Lutheran Protestantism and the use of a language excessively distant from the dialect flourishing in the 'German colonies.'

At the start of the Republic the axis of the discussion over assimilation shifted more clearly to the racial question, a theme absent in this essay except for my references to the idea that immigration could contribute to the Brazilian nation through selective miscegenation. ${ }^{35}$ The ideal immigrant, then, is a white foreigner established in the country, who allows himself to become amalgamated in the national 'melting pot' and adjusts to the Luso-Brazilian cultural canons. This way of seeing immigration and the integration of the immigrant persisted under the New State, a period when xenophobia abounded, condemning 'aliens' and their descendants to forced assimilation. Alien, alienigena in Portuguese, is a word with an ambiguous meaning used to designate both the immigrants (naturalized or otherwise) and their descendants, Brazilians by jus soli, but non-assimilated.

The 'problem of assimilation' reappeared in the Republic, though this failed to produce radical changes in colonization policy, still focused on immigration despite the opening up to include national settlers (colonos), even under the New State (with its plans for occupying the Brazilian central west). The fact that stands out is the identification of immigration with poverty, the immigrant classified as a third class passenger. The most visible consequence of this form of (dis)qualification is the greater detail on the list of undesirables, including beggars, the destitute, indigents, prostitutes and so on. The acceptable poor were those who demonstrated a professional and moral aptitude and were healthy and able to work. On the other hand, the assimilationist pressure might not have been visible in the legislation, but it existed in society and in politics, translated into practice by the 'nationalization

35 Despite considering black slavery to be a component of the nation's formation, the ideal of whitening sustained that this influence would eventually disappear in a process begun with the end of the slave trade in 1850 and the consequent increase in European immigration. Black people could not, therefore, be acceptable immigrants and for many thinkers (see Menezes \& Souza 1875, Oliveira Vianna 1938) accepting them into this category would mean an indirect re-establishment of the slave trade and the renunciation of western civilization. 
campaign' of the New State. After all immigration presumed a definitive process of settlement $t^{36}$ in the country without leeway for cultural plurality, an item included in the field of action of 'national security.'

The sense of definitive residence contained in the representation of immigration is shared by immigrants when they describe the feeling of rupture with the country of birth, expressed in different manners (in the cases presented here, dominated by the image of the ship sailing away from the port of departure or arrival), allowing margin for the embarrassment faced in this liminal situation. The 'bastard' place cited by Bourdieu is more evident in Dörffel's outburst over his statelessness, a 'German settler' without rights, subject to the dictates of the legislation on foreign colonization. However other testimonies are based on the same principle of a loss of identity (in this case, national), although momentary, on disembarking in an unknown place, later superseded by the familiarity encountered in the final destination. For some this destination was already a reality, places that recalled little 'German' towns, where the maternal language was heard. For others the arduous work of clearing the forest was the beginning of the formation of self-contained communities living alongside compatriots, a concrete possibility enabled by the model of 'foreign' colonization.

The probability of staying permanently, however, fades away in the dejected testimony on the difficult life in a colonial nucleus in the process of being formed in the south of Brazil, written by a migrant who later returns to the homeland. Indeed the return, and the way of describing it, show a rejection of the status of immigrant, since the undesired emigration did not lead to settling for good in another country. The problems of colonization, observable in the reports and other documents by colonial administrations (official or private) and in the relevant literature produced by immigrants and others, are not always cited in such a dramatic form to justify the return or even the search for a better life in a town. João Weiss's text, for example, reveals his puzzlement when he saw first-hand the localization of the lot deep in the forest, criticizing the propaganda of the agencies, considering it (like Emilie Heinrichs) overly idyllic, emphasizing above all the ease of access to

36 The idea of definitive settlement, present in some discourses on immigration, certainly does not include the high numbers leaving (and returning). In any case, the returnees ceased to be immigrants, although they remained in the statistical records of entries into Brazil. In the 1940s, the volume of returnees was calculated at 40\%, albeitwith many qualifications of this figure(see Carneiro 1950: 63). 
land. Weiss did not return, but neither did he stay in the colony to where he had been sent with his family, and sent a copy of his text to the Immigration and Colonization Council in 1949, as a contribution to improving the colonization projects involving immigrants. In the end he argued in favour of cultural plurality, saying that a single national culture does not exist in Brazil, a country with regional differences and great cultural distinctiveness produced by many immigratory flows; but the immigrants and their descendants should honour patriotic feelings as Brazilians. Thereze Stutzer, for her part, criticized the colonization system imposed by the State, expounding on her problems, though she lived for some years in a 'German colony,' and thus in a heimisch place, a small and familiar homeland (Heimat). Her writings (and those of her husband) published on their return to Germany, with new editions in the 1920s, served as part of the propaganda encouraging emigration to Brazil with the Germanized Blumenau on the horizon.

Definitive settlement, assuming the identity of an immigrant, and the connection between the process of transnational change and poverty, which appear in the letters and memoirs of individuals we could call common settlers, form points of convergence with the Brazilian discourse on immigration. The form of territorialization of the 'new homeland' - hinted at in immigrants' writings through the familiar image of the older colonies, or connected to an identity that presumes a dual belonging, observable in the desire to overcome the stateless condition, for example, in the hopeful expression of Dörffel - differs radically, though, from the assimilationist imaginary of Brazilian nationalism on European immigration. In this case the awkward immigrants are those who persist in retaining their ethnic, national and cultural difference. A foreigner, an inconvenient 'other', especially when he or she assumes immigration as a definitive process, becoming naturalized, accepting citizenship, while simultaneously rejecting an unrestricted Braziliannness. For the immigrant, naturalization is primarily a political act of social and economic integration, shifting loyalty to the new homeland, yet it does not suppose the passive acceptance of another culture. These are irreconcilable positions that reinforce the embarrassment caused by dual belonging, disrupting the desired unity of the nation state.

Brazilian nationalism produced an image of the ideal immigrant willing to accept the unified formation of the nation, yet immigration in fact produced cultural plurality, or more precisely 'hybrid' cultures. Indeed the 
Germanic configuration observed by new immigrants was being constructed in the subtropical Brazilian landscape in contact (not always immediate in the colonization regions) with Brazilians. Nonetheless the assimilationist precept of nationalism, which flourished under the Republic and became exacerbated as a State policy from the 1930s onwards, allowed the Nation to impose itself on the State, or simply to conceive the State as a manifestation of the Nation, a circumstance signalled by scholars of nationalism (see Arendt 1976, Hobsbawm 1990). In this case the political and social concept of citizenship was augmented by unequivocal criteria of language, race and culture, shaping a premise of 'national community' that supported the extreme measures of 'nationalism' of the New State. The disquiet caused by the irreconcilable immigrant was even manifested in the seizure of the first edition of the Memoirs of Josef Umann, probably due to their quality as a symbol of the colonizing 'epic' and its outcome, an ethnic community.

The ethnicization of the nationality of immigrants, despite the totalizing integration advocated by double-sided assimilationism, was maintained over the long course of foreign colonization, the continuation of which was ensured by the New State's legislation on foreigners. In fact the symbolism of cultural singularity is the main feature of ethnicities, something incompatible with the luso-brazilian configuration of the nation state.

Finally, among the memoirs of immigration we can highlight Clara Hermann's brief mention of her husband, an emigrant born in Germany, an immigrant in Brazil, identified by his supposed compatriots as Brazilian. The narrative does not extend beyond this information, but the attribution of another identity gives an idea of the permanent nature of immigration, associated, in the everyday ideas of German society, with the loss of Germanness, as observed by Willi Ule, the traveller captivated by the 'Germany' discovered in Brazil, the epithet given to the 'Blumenau colony,' by the Brazilians themselves. In reality the paradoxical situation of the Brazilian in Germany and the German in Brazil does not reflect German-Brazilianness and the consequent ethnic identity: on the contrary, the attribution of (apparently) conflicting identities by others (Brazilians and Germans) situates immigrants in the same awkward position as the stateless.

Received: 27/07/2012

Approved: 24/06/2013 
Translated by David Rodgers

Original Language: Portuguese

\section{Bibliography}

ARENDT, Hannah. 1976. As origens do totalitarismo. II. Imperialismo, a expansão do poder. Rio de Janeiro: Editora Documentário.

BALAKRISHNAN, Gopal (ed.). 200o. Um mapa da questão nacional. Rio de Janeiro: Contraponto.

BEIGUELMAN, Paula. 1978. A formação do povo no complexo cafeeiro. 2nded. São Paulo: Pioneira.

BOURDIEU, Pierre. 2004. "Preface." In: Abdelmalek Sayad. The Suffering of the Immigrant. Cambridge:Polity Press.

CARNEIRO, José F. 1950. Imigração e colonização no Brasil. Rio de Janeiro:

Faculdade Nacional de Filosofia, Universidade do Brasil, Cadeira de Geografia do Brasil, Publicação Avulsa, 2.

CARR, William. 1979. A History of Germany. 1815-1945. 2nd ed. London: Edward Arnold.

COHEN, Robin (ed.). 1996. Theories of Migration. Cheltenham: Edward Elgar Publishing Company / The International Library of Studies on Migration. COUTO, R. Ribeiro. 1941. "O problema da nacionalização". Revista de Imigração e Colonização, II (1): 18-38.

FERENCZI, Imre. 1933. "Migration Modern”. Encyclopaedia of the Social Sciences, X, New York: Macmillan, pp. 429-441.

FOUQUET, Carlos. 1974. O imigrante alemão e seus descendentes no Brasil. São

Paulo: Instituto Hans Staden; São Leopoldo: Federação dos Centros

Culturais 25 de Julho.

GELLNER, Ernest. 1983. Nations and nationalism. Oxford: Brackwell.

HOSBSBAWN, Eric J. 1990. Nações e nacionalismo desde 1870. Rio de Janeiro: Paz e Terra.

HUBER, Valburga. 1993. Saudade e Esperança. Blumenau: Ed. FURB.

HUTCHINSON, John e SMITH, Anthony D. (eds.). 1994. Nationalism. Oxford: Oxford University Press.

KULA, Marcin, 1977. "Cartas dos emigrantes do Brasil”. Anais da Comunidade Brasileira Polonesa, VIII, pp. 9-117.

LACERDA, João B. 1911. Sur lês métis au Brésil. Paris: Imprimerie Devouge. 
LANGE, Wilhelm G. 2003. Testemunho de Fé. Blumenau: Nova Letra.

MACHADO, Cacilda da Silva. 1998. De uma familia imigrante. Curitiba: Aos Quatro Ventos.

MAUSS, Marcel. 1969. Oeuvres. 3. Cohesion Sociale et divisions de la Sociologie. Paris: Les Editions de Minuit.

MENEZES E SOUZA, J. C. de. 1875. Theses sobre a colonização do Brasil. Rio de Janeiro: Imprensa Nacional.

NEIVA, Artur Hehl. 1944. “O problema imigratório brasileiro”. Revista de Imigração e Colonização, 5 (3): 468-591.

OLIVEIRA VIANNA, F. J. 1938. Evolução do povo brasileiro. 3rd ed. São Paulo: Cia. Editora Nacional.

ROCHA, Joaquim da Silva. 1918. História da Colonização do Brasil.2 vols. Rio de Janeiro, Imprensa Nacional.

SEYFERTH, Giralda. 1991. “Os paradoxos da miscigenação”. Estudos Afro Asiáticos, 20: 165-185.

SEYFERTH, Giralda. 1999. "Colonização e conflito”. In: José V. T. dos Santos (ed.) Violência em tempo de globalização. São Paulo, Hucitec, pp: 285-330.

SEYFERTH, Giralda. 2002. “Colonização, imigração e a questão racial no Brasil". Revista da USP, 53: 117-149.

SEYFERTH, Giralda. 2004. "A idéia de cultura teuto-brasileira: literatura, identidade e os significados da etnicidade”. Horizontes Antropológicos, 22: 149-197.

SEYFERTH, Giralda. 2005. "Cartas e narrativas biográficas no estudo da imigração”. In: Zeila A. B. F. Demartini, e Oswaldo M. S. Truzzi (eds.) Estudos Migratórios. Perspectivas metodológicas. São Carlos: EDUFSCar, pp. 13-52.

STOLTZ, Roger. 1997. Cartas de Imigrantes. Porto Alegre: Edições EST.

STUTZER, Therese. 1889. Deustsches Leben am brasilianischen Urwalds. Gotha: Andreas Perthes.

TAVARES BASTOS, A. C. 1976. Os males do presente e as esperanças do futuro. São Paulo: Cia. Ed. Nacional: Brasília, INL.

UMANN, Josef. 1981. Memórias de um imigrante boêmio. Porto Alegre: EST. VOGT, Andre F. 2004. Cartas reveladas. Blumenau: Editora Cultura em Movimento.

WARE, Caroline F. 1933. "Immigration”. Encyclopaedia of the Social Sciences, v. VII, New York: Macmillan, pp. 587-595.

WEBER, Max. s/d. Ensaios de Sociologia. Rio de Janeiro: Zahar. 
WEBER, Max. 1991. Economia e Sociedade, v. 1. Brasília: Editora da Universidade de Brasília.

WEISS, João. 1949. Colonos na selva. Rio de Janeiro: Edição do Autor. 